Check for updates

Cite this: RSC Adv., 2019, 9, 22011

\title{
Lonimacranaldes $A-C$, three iridoids with novel skeletons from Lonicera macranthoides $\uparrow$
}

\author{
Yu-Dan Mei,,$_{+}{ }^{a b}$ Hai-Bo Li,,${ }_{+}^{c}$ Qian-Qian Pang, ${ }^{a}$ Ting Li, ${ }^{a}$ Da-Bo Pan, ${ }^{a}$ Yi Dai, ${ }^{a}$

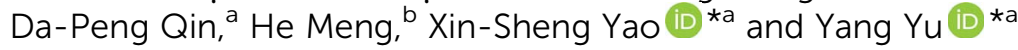

Lonimacranaldes A and B ( 1 and 2 ), along with one biogenetically related intermediate, lonimacranalde C (3), were isolated from the flower buds of Lonicera macranthoides. Characterized by an iridoid structure and an additional C- 6 unit with an aldehyde group, compounds 1 and 2 are the first examples of hybrid iridoids possessing an unexpected 6/5/6 fused tricyclic ring system, while compound 3 serves as an important precursor for their generation. The structures of lonimacranaldes A-C (1-3) were revealed by extensive spectroscopic and X-ray diffraction analyses. A plausible biogenetic pathway for them was proposed. Compound 3 showed antiinflammatory activities by inhibiting the production of IL- 6 on LPS-induced RAW 264.7 cells with an $\mathrm{IC}_{50}$ value of $6.33 \mu \mathrm{M}$.

Received 28th May 2019

Accepted 8th July 2019

DOI: $10.1039 / c 9 r a 04029 c$

rsc.li/rsc-advances

In our continuous efforts to discover new bioactive iridoids

\section{Introduction}

Naturally occurring iridoids with a cyclopenta $[c]$ pyran skeleton are monoterpenoids which usually exist as glycosides with a monosaccharide group at C-1. ${ }^{1}$ Cleavage of the $\mathrm{C}-7$ and $\mathrm{C}-8$ bonds of the cyclopentane ring of iridoids affords a subclass known as secoiridoids. Iridoids possess a broad range of biological activities such as hepatoprotective, ${ }^{2,3}$ anti-inflammatory, ${ }^{4,5}$ antitumor, ${ }^{6,7}$ antimicrobial, ${ }^{8}$ allelopathic, ${ }^{\mathbf{9}}$ hypoglycemic, ${ }^{\mathbf{1 0}}$ cardiovascular, ${ }^{\mathbf{1 1}}$ choleretic, antispasmodic, antiviral, and immunomodulatory activity. ${ }^{12,13}$

Lonicera macranthoids Hand.-Mazz., an important source of Lonicerae Flos (also Shan Yin-Hua in Chinese), are commonly used in traditional Chinese medicine (TCM) for its similar heatclearing and detoxicating effects as those of Lonicerae japonicae Flos (Jin Yin-Hua). Our previous studies on the $70 \% \mathrm{EtOH}$ extract of the flower buds of $L$. macranthoides resulted in the isolation of 11 chlorogenic acids and 12 triterpenoids, including three new chlorogenic acids with a monoterpene unit and two anti-inflammatory triterpenoids. ${ }^{\mathbf{1 4 , 1 5}}$

anstitute of Traditional Chinese Medicine \& Natural Products, College of Pharmacy, Jinan University, Guangzhou 510632, P. R. China. E-mail: 1018yuyang@163.com; tyaoxs@jnu.edu.cn; Fax: +86-20-85221559; Tel: +86-20-85221559

${ }^{b}$ Xiangxue Academician Workstation, Xiangxue Pharmaceutical Co. Ltd., Guangzhou, 510663, P. R. China

'Jiangsu Kanion Pharmaceutical Co., Ltd., State Key Laboratory of New-tech for Chinese Medicine Pharmaceutical Process, Jiangsu, Lianyungang, 222001, China

$\dagger$ Electronic supplementary information (ESI) available: NMR spectra of all new compounds. CCDC 1877498. For ESI and crystallographic data in CIF or other electronic format see DOI: $10.1039 / \mathrm{c} 9 \mathrm{ra04029c}$

\$ These authors have contributed equally to this work. from the flower buds of Lonicera macranthoids, three iridoids with novel skeletons (lonimacranaldes A-C, 1-3) were isolated unexpectedly. The common structural feature among 1-3 was biogenetically derived from two precursors, an iridoid (secologanic acid, 4) and a volatile component with C-6 unit (hexanal, 5), both of which had been reported in Lonicera genus before. $^{\mathbf{1 6 , 1 7}}$ Obviously, the aldol condensation of the two precursors led to 3, while 1 and 2 might be derived from 3 by an oxidative reaction and an intramolecular Diels-Alder reaction to form an unexpected 6/5/6 fused tricyclic ring skeleton system (Fig. 1, rings A/B/C). Herein, we reported the isolation, structure elucidation, and plausible biosynthetic pathway of 1-3, and their potential anti-inflammatory activities.

\section{Results and discussion}

Lonimacranalde A (1) was obtained as white powder and subsequently crystallized from $\mathrm{EtOH} / \mathrm{H}_{2} \mathrm{O}$ as colorless needles with negative rotation $\left([\alpha]_{\mathrm{D}}^{28}-18.7, c=0.6\right.$, in $\left.\mathrm{CH}_{3} \mathrm{OH}\right)$. The UV
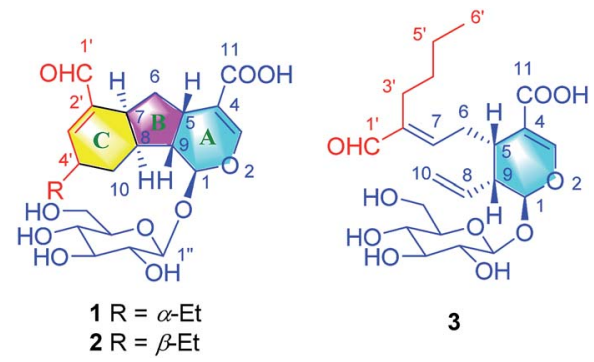

Fig. 1 Chemical structures of compounds 1-3. 
spectrum showed a characteristic absorption maximum of iridoid at $232 \mathrm{~nm}(\log \varepsilon$ 3.9), while the IR spectrum showed an absorption band of hydroxyl (3366 $\mathrm{cm}^{-1}$ ) and carbonyl $\left(1700 \mathrm{~cm}^{-1}\right)$. Its molecular formula was determined as $\mathrm{C}_{22} \mathrm{H}_{30} \mathrm{O}_{10}$ based on HR-ESI-Q-TOF-MS $(m / z \text { 477.1747 [M }+\mathrm{Na}]^{+}$, calcd for $\left.\mathrm{C}_{22} \mathrm{H}_{30} \mathrm{O}_{10} \mathrm{Na}, 477.1737\right)$. The ${ }^{1} \mathrm{H}$ NMR spectrum of 1 exhibited characteristic signals of iridoid glycoside, including an acetal proton $\left[\delta_{\mathrm{H}} 5.21(1 \mathrm{H}, \mathrm{d}, J=7.1 \mathrm{~Hz}, \mathrm{H}-1)\right]$, a trisubstituted olefinic proton $\left[\delta_{\mathrm{H}} 7.48(1 \mathrm{H}, \mathrm{d}, J=1.2 \mathrm{~Hz}, \mathrm{H}-3)\right]$, and an anomeric proton $\left[\delta_{\mathrm{H}} 4.72\left(1 \mathrm{H}, \mathrm{d}, J=7.9 \mathrm{~Hz}, \mathrm{H}-1^{\prime \prime}\right)\right]$. In addition, a proton signal assignable to an aldehyde group $\left[\delta_{\mathrm{H}}\right.$ $\left.9.38\left(1 \mathrm{H}, \mathrm{s}, \mathrm{H}-\mathbf{1}^{\prime}\right)\right]$ was also observed. The sugar moiety of 1 was determined to be D-glucose by HPLC analysis after acid hydrolysis and glycosyl derivatization. Combined with the $J$ value of the anomeric proton mentioned above, a $\beta$-D-glucosyl residue was deduced.

Besides signals attributable to a glucosyl residue, the rest carbons were revealed as two carbonyls $\left(\delta_{\mathrm{C}} 196.4,170.9\right)$, two trisubstituted double bonds $\left(\delta_{\mathrm{C}} 158.1,153.5,145.1,112.2\right)$, and ten $\mathrm{sp}^{3}$ carbons, which comprised six methines $\left(\delta_{\mathrm{C}} 98.6,46.1,38.4\right.$, $36.1,35.7,35.2)$, three methylenes $\left(\delta_{\mathrm{C}} 38.9,32.1,28.7\right)$, and a methyl $\left(\delta_{\mathrm{C}} 11.8\right)$ according to ${ }^{13} \mathrm{C}$ NMR and DEPT 135 spectra. All of the proton and carbon signals were assignable by COSY, HSQC, and HMBC spectra (Table S1 $\dagger$ ).

The aglucone of compound 1 was determined by the COSY correlations of $\mathrm{H}-1 / \mathrm{H}-9(\mathrm{H}-8) / \mathrm{H}-5 / \mathrm{H}_{2}-6 / \mathrm{H}-7 / \mathrm{H}-8 / \mathrm{H}_{2}-10 / \mathrm{H}-4^{\prime}(\mathrm{H}-$ $\left.3^{\prime}\right) / \mathrm{H}_{2}-5^{\prime} / \mathrm{H}_{3}-6^{\prime}$, together with the HMBC correlations of $\mathrm{H}-3$ / $\mathrm{C}-1,4,5,11, \mathrm{H}-1 / \mathrm{C}-3,5,8,9$ and $\mathrm{H}-1^{\prime} / \mathrm{C}-7,2^{\prime}, 3^{\prime}$, (Fig. 2). Moreover, other HMBC correlations of $\mathrm{H}-1^{\prime \prime} / \mathrm{C}-1$ and $\mathrm{H}-1 / \mathrm{C}-1^{\prime \prime}$ revealed that the $\beta$-D-glucosyl was located at $\mathrm{C}-1$. Hence, the planar structure of compound 1 was established.

The cyclopentanopyran ring in iridoids was commonly $\mathrm{H}-5$ / $\mathrm{H}-9 \quad \beta, \beta$-cis-fused, while $\mathrm{H}-1 \quad \alpha$-oriented. Since the C-1 resonance was at $\delta 98.6$ (compared to $\delta 101-103$ for trans-fused iridoids) and the allylic coupling of the $\mathrm{H}-3 / \mathrm{H}-5$ resonances was $1.2 \mathrm{~Hz}$ (compared to $2.0-2.5 \mathrm{~Hz}$ for trans-fused iridoids), ${ }^{\mathbf{1 4}, 18}$ the $\mathrm{H}-5 / \mathrm{H}-9$ in 1 could be preliminarily assumed as $\beta, \beta$-cis-fused. Then, based on the NOE correlations of $\mathrm{H}_{2}-6 / \mathrm{H}-1, \mathrm{H}-1 / \mathrm{H}-7$ and $\mathrm{H}-1 / \mathrm{H}-8, \mathrm{~A} / \mathrm{B}$ and $\mathrm{B} / \mathrm{C}$ rings in 1 were determined as $\mathrm{H}-5 / \mathrm{H}-9) \beta, \beta-$ cis-fused, and $\mathrm{H}-7 / \mathrm{H}-8 \alpha, \alpha$-cis-fused, respectively. Furthermore, the NOE correlations of $\mathrm{H}-4^{\prime} / \mathrm{H}-9$ indicated that $\mathrm{H}-4^{\prime}$ was $\beta$ oriented. For the deductions above, the relative configurations in 1 were all consistent with the absolute configurations determined by X-ray (Fig. 3). Consequently, the structure of 1 was unmistakably and completely confirmed and named lonimacranalde A.

Lonimacranalde B (2), isolated as colorless needle $\left([\alpha]_{\mathrm{D}}^{28}-\right.$ 9.7, $c=0.6$, in $\mathrm{CH}_{3} \mathrm{OH}$ ), has the same molecular formula with 1 based on the HR-ESI-MS data. The ${ }^{1} \mathrm{H}$ NMR and ${ }^{13} \mathrm{C}$ NMR data of 2 were assignable by COSY, HSQC, and HMBC spectra (Table $\mathrm{S} 1 \dagger)$, which were highly similar to 1 , suggesting that they were two isomers.

Table $1{ }^{1} \mathrm{H}$ NMR and ${ }^{13} \mathrm{C}$ NMR data for compounds $1-3^{a}$

\begin{tabular}{|c|c|c|c|c|c|c|}
\hline \multirow[b]{2}{*}{ No. } & \multicolumn{2}{|l|}{1} & \multicolumn{2}{|l|}{2} & \multicolumn{2}{|l|}{3} \\
\hline & $\delta_{\mathrm{C}}$ & $\delta_{\mathrm{H}}(J$ in $\mathrm{Hz})$ & $\delta_{\mathrm{C}}$ & $\delta_{\mathrm{H}}(J$ in $\mathrm{Hz})$ & $\delta_{\mathrm{C}}$ & $\delta_{\mathrm{H}}(J$ in $\mathrm{Hz})$ \\
\hline 1 & 98.6 & $5.21, \mathrm{~d}(7.1)$ & 97.2 & $5.35, \mathrm{~d}(5.9)$ & 97.7 & $5.55, \mathrm{~d},(5.6)$ \\
\hline 3 & 153.5 & $7.48, \mathrm{~d}(1.2)$ & 153.4 & $7.49, \mathrm{~d}(1.1)$ & 153.9 & $7.52, \mathrm{~d}(1.1)$ \\
\hline 4 & 112.2 & & 113.0 & & 110.8 & \\
\hline 5 & 35.2 & $2.68, \mathrm{q}(7.8)$ & 33.6 & 3.06, ddd $(8.8,8.0,4.3)$ & 33.5 & 3.04 \\
\hline 6 & 38.9 & $\begin{array}{l}2.00, \text { ddd }(13.0,6.7,4.4) \\
1.85\end{array}$ & 37.8 & $\begin{array}{l}2.23 \\
1.68, \text { ddd }(13.3,10.5,8.8)\end{array}$ & 30.2 & $\begin{array}{l}2.50, \text { ddd }(15.2,8.0,7.0) \\
2.99 \text { ddd }(15.2,7.0,7.0)\end{array}$ \\
\hline 7 & 35.7 & 2.89 & 34.7 & $2.79, \mathrm{q}(9.0)$ & 155.5 & $6.63, \mathrm{t}(7.0)$ \\
\hline 8 & 38.4 & 2.47 & 40.4 & 2.25 & 135.4 & 5.77, ddd $(17.1,10.4,9.0)$ \\
\hline 9 & 46.1 & $1.94, \operatorname{td}(7.8,4.8)$ & 48.8 & 2.09, ddd $(8.0,5.9,2.5)$ & 45.4 & $2.70, \mathrm{dt}(9.0,5.6)$ \\
\hline 10 & 32.1 & $\begin{array}{l}1.88 \\
1.40, \text { ddd }(13.6,9.1,4.6)\end{array}$ & 33.7 & $\begin{array}{l}\text { 1.88, ddd }(13.0,5.0,4.6) \\
1.13, \text { ddd }(13.0,13.0,11.1)\end{array}$ & 120.0 & $5.27, \mathrm{~m}$ \\
\hline 11 & 170.9 & & 170.9 & & 170.4 & \\
\hline $1^{\prime}$ & 196.4 & $9.38, \mathrm{~s}$ & 196.5 & $9.40, \mathrm{~s}$ & 197.1 & $9.33, \mathrm{~s}$ \\
\hline $2^{\prime}$ & 145.1 & & 145.3 & & 145.6 & \\
\hline $3^{\prime}$ & 158.1 & $6.93, \mathrm{~d}(2.8)$ & 157.0 & $6.80, \mathrm{~d}(2.0)$ & 24.8 & 2.21 \\
\hline $4^{\prime}$ & 36.1 & 2.30 & 40.0 & 2.30 & 32.0 & 1.30 \\
\hline $5^{\prime}$ & 28.7 & $\begin{array}{l}1.57, \text { ddq }(14.0,14.0,7.4) \\
1.48, \operatorname{ddq}(14.0,14.0,7.4)\end{array}$ & 28.8 & $\begin{array}{l}1.59, \operatorname{ddq}(14.0,14.0,7.4) \\
1.51, \mathrm{ddq}(14.0,14.0,7.4)\end{array}$ & 23.8 & 1.30 \\
\hline $6^{\prime}$ & 11.8 & $1.05, \mathrm{t}(7.4)$ & 11.5 & $1.03, \mathrm{t}(7.4)$ & 14.2 & $0.91, \mathrm{t}(7.0)$ \\
\hline $1^{\prime \prime}$ & 100.3 & $4.72, \mathrm{~d}(7.8)$ & 100.3 & $4.67, \mathrm{~d}(7.9)$ & 100.2 & $4.69, \mathrm{~d}(7.9)$ \\
\hline $2^{\prime \prime}$ & 74.8 & 3.21, dd $(9.0,7.8)$ & 74.7 & 3.21, dd $(9.2,7.9)$ & 74.7 & 3.20, dd $(9.2,7.9)$ \\
\hline $3^{\prime \prime}$ & 78.0 & $3.39, \mathrm{t}(8.7)$ & 78.0 & 3.38, dd $(9.2,8.7)$ & 78.0 & 3.37 , dd $(9.2,8.9)$ \\
\hline $4^{\prime \prime}$ & 71.6 & 3.29 & 71.6 & 3.29 & 71.6 & 3.28, dd $(9.7,8.9)$ \\
\hline $5^{\prime \prime}$ & 78.4 & 3.30 & 78.3 & 3.30 & 78.4 & 3.31 \\
\hline $6^{\prime \prime}$ & 62.8 & $\begin{array}{l}3.90, \text { dd }(11.9,2.1) \\
3.67, \text { dd }(11.9,5.9)\end{array}$ & 62.7 & $\begin{array}{l}3.86, \text { dd }(11.9,1.9) \\
3.65, \text { dd }(11.9,5.4)\end{array}$ & 62.7 & $\begin{array}{l}3.89, \text { dd }(11.9,2.2) \\
3.66, \text { dd }(11.8,5.8)\end{array}$ \\
\hline
\end{tabular}

${ }^{a}$ Recorded at $600\left({ }^{1} \mathrm{H}\right)$ and $150 \mathrm{MHz}\left({ }^{13} \mathrm{C}\right)$ in $\mathrm{CD}_{3} \mathrm{OD}$. Multiplets or overlapped signals are reported without designating multiplicity. 


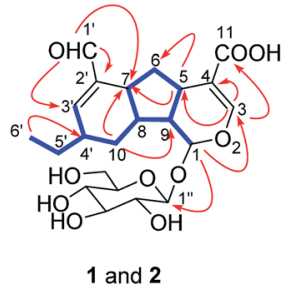

$-{ }^{1} \mathrm{H}^{1} \mathrm{H} \operatorname{COSY}$
$\sim{ }_{\mathrm{HMBC}}$

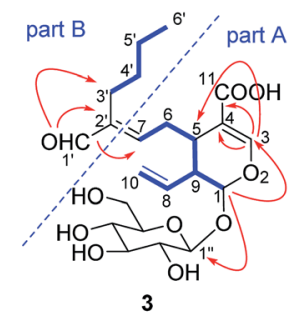

Fig. 2 Key ${ }^{1} \mathrm{H}-{ }^{1} \mathrm{H}$ COSY, HMBC, and ROESY correlations of $1-3$

There is no single crystal data of $\mathbf{2}$, so its configurations were solved by analyzing the coupling constants and NOESY data, as well as the CD spectrum. Similarly, for the NOE correlations of $\mathrm{H}-6\left(\delta_{\mathrm{H}} 2.23\right) / \mathrm{H}-1, \mathrm{H}-1 / \mathrm{H}-7$ and $\mathrm{H}-1 / \mathrm{H}-8, \mathrm{~A} / \mathrm{B}$ and $\mathrm{B} / \mathrm{C}$ rings in 2 were determined as $\beta, \beta$-cis-fused and $\alpha, \alpha$-cis-fused, respectively, as well. The coupling constants of $\mathrm{H}-10 \mathrm{a}, \mathrm{H}-4^{\prime}$, and $\mathrm{H}-8\left(J_{10 \mathrm{a}, 4^{\prime}}=11.0 \mathrm{~Hz}, J_{10 \mathrm{a}, 8}=11.0 \mathrm{~Hz}\right)$ indicated that $\mathrm{H}-10 \mathrm{a} / \mathrm{H}-4^{\prime}$ and $\mathrm{H}-10 \mathrm{a} / \mathrm{H}-8$ were aa coupling. Since that, $\mathrm{H}-4^{\prime}$ was $\beta$-oriented as $\mathrm{H}-8$. It also meant that the dominant conformation of ring $\mathrm{C}$ in compound 2 was the same as 1 with $4^{\prime}$-ethyl in equatorial bond. The NOE correlations of $\mathrm{H}-9 / \mathrm{H}_{2}-10$ and $\mathrm{H}-10 \mathrm{~b}\left(\delta_{\mathrm{H}} 1.88\right) / \mathrm{H}_{3}-6$ further provided more evidences for such deduction (Fig. 4). Obviously, 2 was a C-4' epimer of $\mathbf{1}$, which can further be validated by their experimental CD spectra with the same Cotton effects (Fig. 5). In conclusion, compound 2 was determined and named lonimacranalde $\mathrm{B}$.

Lonimacranalde $\mathrm{C}$ (3), obtained as light yellow powder $\left([\alpha]_{\mathrm{D}}^{28}-150.4, c=0.3\right.$, in $\left.\mathrm{CH}_{3} \mathrm{OH}\right)$, its molecular formula was determined as $\mathrm{C}_{22} \mathrm{H}_{32} \mathrm{O}_{10}$ on the basis of the HR-ESI-MS data $\left(m / z 479.1895[\mathrm{M}+\mathrm{Na}]^{+}\right.$, calcd for $\mathrm{C}_{22} \mathrm{H}_{32} \mathrm{O}_{10} \mathrm{Na}$ : 479.1893). Compound 3 was considered as a secoiridoid-type glycoside for the typical protons attributed to an acetal $\left[\delta_{\mathrm{H}} 5.55(1 \mathrm{H}, \mathrm{d}, J=\right.$ $5.6 \mathrm{~Hz}, \mathrm{H}-1)]$, a tri-substituted olefinic proton $\left[\delta_{\mathrm{H}} 7.52(1 \mathrm{H}, \mathrm{d}, J=\right.$ $1.1 \mathrm{~Hz}, \mathrm{H}-3)]$, and a mono-substituted vinyl group $\left[\delta_{\mathrm{H}} 5.77(1 \mathrm{H}\right.$, ddd, $\left.J=17.1,10.4,8.9 \mathrm{~Hz}, \mathrm{H}-8), 5.27\left(2 \mathrm{H}, \mathrm{m}, \mathrm{H}_{2}-10\right)\right]$, together with an anomeric proton $\left[\delta_{\mathrm{H}} 4.69\left(1 \mathrm{H}, \mathrm{d}, J=7.9 \mathrm{~Hz}, \mathrm{H}-1^{\prime}\right)\right]$. Additionally, the sugar moiety in 3 was identified as $\beta$-D-glucosyl by comparing the NMR data with 1 .

According to the COSY correlations of $\mathrm{H}-1 / \mathrm{H}-9 / \mathrm{H}-5 / \mathrm{H}_{2}-6 / \mathrm{H}-$ 7 and $\mathrm{H}-9 / \mathrm{H}-8 / \mathrm{H}_{2}-10$, as well as the HMBC correlations of $\mathrm{H}-1 /$
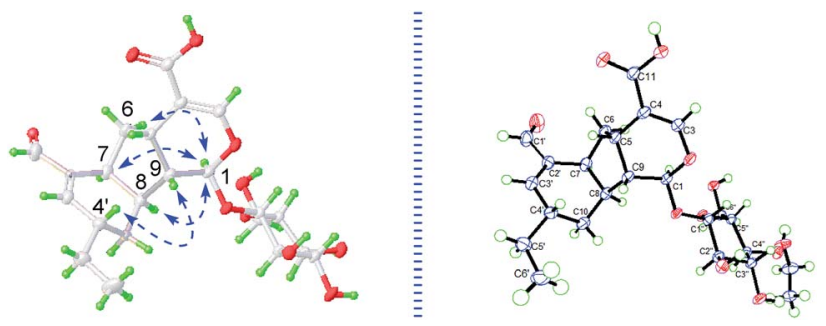

Fig. 3 Key NOESY correlations and X-ray crystallographic analysis of 1.

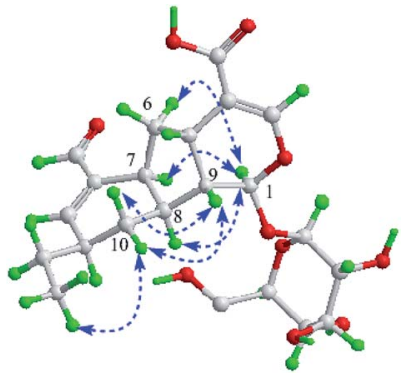

Fig. 4 Key NOESY correlations of 2.

C-1", 3, and H-3/C-4, 5, 11, a 7-substituted secologanic acid moiety in 3 was established (part A, Fig. 2). Except for the structure of part A, the rest six carbon signals included four $\mathrm{sp}^{3}$ carbons, an olefinic quaternary carbon, and an aldehyde. Thereafter, a hexanal moiety was further confirmed by the COSY correlations of $\mathrm{H}_{2}-3^{\prime} / \mathrm{H}_{2}-4^{\prime} / \mathrm{H}_{2}-5 /{ }^{\prime} \mathrm{H}_{3}-6^{\prime}$ and the HMBC correlations of $\mathrm{H}-1^{\prime} / \mathrm{C}-2^{\prime}, 3^{\prime}$ (part B, Fig. 2). Moreover, part A and part B in 3 were linked through the $\mathrm{C}-7 / \mathrm{C}-2^{\prime}$ double bond, which was verified by the HMBC correlations of $\mathrm{H}-1^{\prime} / \mathrm{C}-7$. Thus, the planar structure of $\mathbf{3}$ was established and data assignment was shown in Table 1.

The NOE correlations of $\mathrm{H}-1 / \mathrm{H}-6, \mathrm{H}-1 / \mathrm{H}-8$, and $\mathrm{H}-1 / \mathrm{H}-7$ revealed that $\mathrm{H}-1 / \mathrm{H}-6 / \mathrm{H}-8$ and $\mathrm{H}-5 / \mathrm{H}-9$ in 3 were of the opposite configurations, suggesting that the relative configurations in 3 were consistent with the common secoiridoids. Thus, it could be concluded that the absolute configurations in 3 were identical with secologanic acid and defined as $1 S / 5 S / 9 R$. Furthermore, the correlation of $\mathrm{H}-1^{\prime} / \mathrm{H}-$ 7 observed in the NOESY spectrum revealed that the geometry of the double bond (C-7/C-2') was $E$-configuration. In conclusion, 3 was identified as lonimacranalde C.

A plausible biosynthetic pathway, involving an aldol condensation, an oxidative reaction and a key Diels-Alder reaction, was proposed for lonimacranaldes A-C (1, 2 and 3) (Scheme 1). It's obvious that compound 3 was originated from 4 and 5 by an aldol condensation, which occurs frequently in 7$\mathrm{CHO}$ of secologanic acid or secologanin to provide diverse unusual structures. ${ }^{1719-21}$ Then, the oxidation of 3 led to the intermediates (6a and $\mathbf{6 b}$ ), which were never isolated, but might

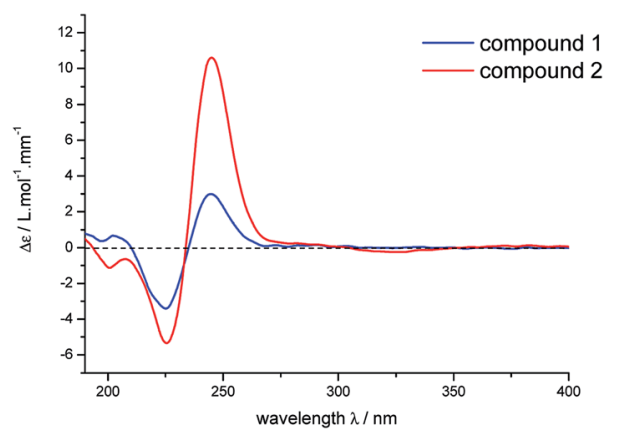

Fig. 5 Experimental CD spectra of 1 and 2. 


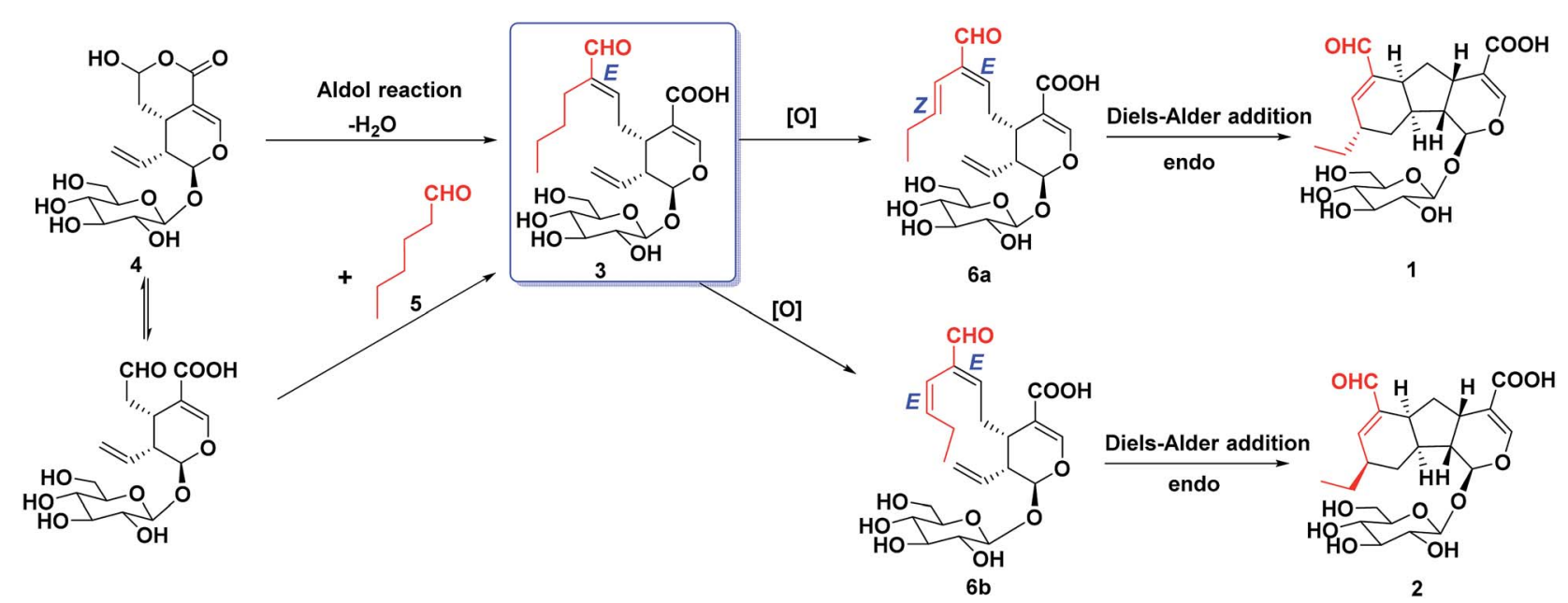

Scheme 1 Plausible biosynthetic pathway of 1,2 and 3.

to generate 1 and 2 through a $[4+2]$ cycloaddition. The cycloaddition has endo preference and occurs with remote stereocontrol syn to the substituent at the stereogenic center, which can explain the epimerization of $\mathbf{1}$ and $\mathbf{2}$ in a certain extent. ${ }^{22,23}$ This plausible biogenetic pathway of 1-3 has not been validated, but it provides a reference for their biosynthesis and total synthesis.

Anti-inflammatory activities of lonimacranaldes A-C (1, 2 and 3) were evaluated in LPS-stimulated RAW 264.7 cells, including NO (nitric oxide), IL-6 (interleukin 6) and TNF$\alpha$ (tumor necrosis factor) inhibitory activities. As a result, compound 3 exhibited inhibitory effect on IL-6 with an IC 50 value of $6.33 \mu \mathrm{M}$ (Fig. 6). Unfortunately, none of them displayed TNF- $\alpha$ and NO inhibitory activity at $100 \mu \mathrm{M}$.

In order to confirm that compounds 1-3 are indeed natural products, the crude methanol extract of dried flower buds of $L$. macranthoides was analyzed by UPLC-Q-TOF-MS (see the ESI $\dagger$ ). The ion peaks in accord with those of 1-3 were detected, which confirmed the natural occurrence of these compounds.

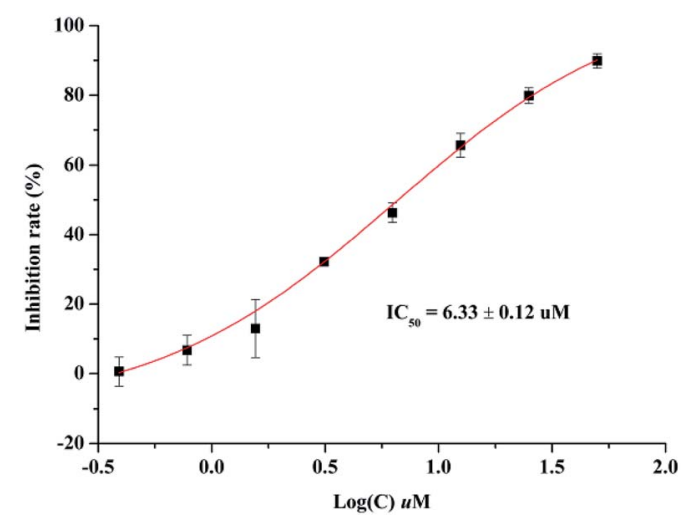

Fig. 6 Effect of compound 3 on IL-6 production in LPS-stimulated RAW 264.7 cells.

\section{Conclusions}

In conclusion, we have isolated three novel hybrid iridoids, lonimacranaldes A-C (1-3) from the flower buds of Lonicera macranthoides. Their unique architectures and remarkable antiinflammatory activities of compound 3 should receive considerable attention from synthetic chemists and pharmacologists.

\section{Experimental}

\section{General experimental procedures}

${ }^{1} \mathrm{H}$ and ${ }^{13} \mathrm{C}$ NMR spectra were measured on a Bruker AV 600 (Bruker Co. Ltd., Bremen, German) at 600 and $150 \mathrm{~Hz}$ with solvent signals $\left(\mathrm{CD}_{3} \mathrm{OD}, \delta_{\mathrm{H}} 3.10 / \delta_{\mathrm{C}} 49.0\right)$ as internal reference. IR spectra were taken on a JASCO FT/IRBCA plus spectrometer (JASCO International Co. Ltd., Tokyo, Japan) with KBr. UV spectra were acquired using a JASCO V-550 UV/Vis spectrometer (JASCO International Co. Ltd., Hachioji, Tokyo, Japan). Optical rotation was measured on JASCO P-1020 digital polarimeter (JASCO International Co. Ltd., Hachioji, Tokyo, Japan). ECD spectra were recorded in methanol using a JASCO J-810 spectrophotometer (Jasco Internal Co. Ltd, Tokyo, Japan). HRESIMS spectra were measured on a Waters Synapt G2 mass spectrometer (Waters, Manchester, U. K.) with a RP-18 column (1.7 m, $\phi$ $3.0 \times 150 \mathrm{~mm}$; BEH). HPLC analyses were performed on a Waters 2695 separations module (Waters, Manchester, U.K.) equipped with a 2998 photodiode array (PDA) detector and an Alltech 3300 evaporative light scattering detector (ELSD; Alltech Inc., Deerfield, Illinois, U.S.A.) using a Phenomenex Gemini C18 column ( $5 \mu \mathrm{m}, \phi 4.6 \times 250 \mathrm{~mm}$; FLM Inc., Guangzhou, China). The semi-preparative HPLC analyses were performed on a Waters 1515 isocratic HPLC pump (Waters, Manchester, U.K.) coupled with a $2489 \mathrm{UV} /$ Vis detector (Waters, Manchester, U.K.) and a Phenomenex Gemini C18 column $(5 \mu \mathrm{m}, \phi 10 \times 250 \mathrm{~mm}$; FLM Inc., Guangzhou, China). The methanol of HPLC grade was purchased from BCR International Co. Ltd. (Shanghai, China), while the acetonitrile was purchased from Merck (Darmstadt, 
Germany). Diaion HP-20 (Mitsubishi Chemical Co., Tokyo, Japan), silica gel (200-300 mesh, Qingdao Marine Chemical Ltd., Shandong, China), ODS-silica gel (12 nm, S-50 $\mu \mathrm{m}$, YMC Ltd., Tokyo, Japan) and Sephadex LH-20 (Amersham Pharmacia Biotech, Sweden) were used for chromatography column (CC). TLC was performed on pre-coated silica gel plate $\left(\mathrm{SGF}_{254}, 0.2\right.$ $\mathrm{mm}$, Yantai Chemical Industry Research Institute, Shandong, China).

\section{Plant material}

Dried flower buds of $L$. macranthoides were collected in Shandong Province and purchased from Kunyuan Pharmaceutical Co., Ltd. in Nov, 2014, and identified by Prof. G. X. Zhou of Jinan University. A sample (no. LM201411) is deposited in Jinan University, Guangzhou, China.

\section{Extraction and isolation}

The dried flower buds of $L$. macranthoides (35 kg) were extracted twice with $70 \%$ ethanol $(280 \mathrm{~L}$, for $2 \mathrm{~h}$ each time) under reflux. The ethanol was evaporated under vacuum, affording a crude extract $(8.5 \mathrm{~kg})$, which was suspended in water and then subjected to an HP-20 macroporous resin CC $(\phi 20 \times 85 \mathrm{~cm})$ eluted with $\mathrm{EtOH}-\mathrm{H}_{2} \mathrm{O}(0: 100,30: 70,50: 50,5: 95, \mathrm{v} / \mathrm{v})$ to offer four fractions (LM-1-LM-4). LM-3 (700 g) was chromatographed over a silica gel CC $(\phi 110 \times 420 \mathrm{~cm})$ by using a $\mathrm{CHCl}_{3}-\mathrm{CH}_{3} \mathrm{OH}-\mathrm{H}_{2} \mathrm{O}$ gradient ( $95: 5: 0$ to $60: 40: 8, \mathrm{v} / \mathrm{v} / \mathrm{v}$ ), yielding sixteen fractions (3A-3P). Fraction $3 \mathrm{E}(17.7 \mathrm{~g})$ was separated by ODS $(\phi 3.3 \times 33$ $\mathrm{cm}$ ) eluted with $\mathrm{CH}_{3} \mathrm{OH}-\mathrm{H}_{2} \mathrm{O}(30: 70$ to $100: 0, \mathrm{v} / \mathrm{v})$ to offer eleven subfractions E1-E11. Fractions E6, was separated on a silica gel $\mathrm{CC}\left(\mathrm{CHCl}_{3}-\mathrm{CH}_{3} \mathrm{OH}-\mathrm{H}_{2} \mathrm{O}, 80: 20: 2, \mathrm{v} / \mathrm{v} / \mathrm{v}\right)$, Sephadex LH-20 CC $\left(\mathrm{CH}_{3} \mathrm{OH}-\mathrm{H}_{2} \mathrm{O}, 50: 50, \mathrm{v} / \mathrm{v}\right)$, followed semipreparative HPLC $\left(\mathrm{CH}_{3} \mathrm{CN}-\mathrm{H}_{2} \mathrm{O}-\mathrm{HCOOH}, 25: 75: 0.1, \mathrm{v} / \mathrm{v} / \mathrm{v}\right)$ respectively, to yield $1\left(t_{\mathrm{R}}: 15.3 \mathrm{~min}, 7.7 \mathrm{mg}\right)$ and $2\left(t_{\mathrm{R}}: 17.0 \mathrm{~min}, 4.7 \mathrm{mg}\right)$, while fractions E10 was purified by semipreparative HPLC $\left(\mathrm{CH}_{3} \mathrm{CN}-\right.$ $\mathrm{H}_{2} \mathrm{O}-\mathrm{HCOOH}, 30: 70: 0.1$, v/v/v) to furnish $3\left(t_{\mathrm{R}}: 22.3 \mathrm{~min}, 2.0\right.$ $\mathrm{mg})$.

Lonimacranalde A (1). White powder; $[\alpha]_{\mathrm{D}}^{28}-18.7$ (c 0.6 , $\mathrm{CH}_{3} \mathrm{OH}$ ); ESI-MS: $m / z 477$ [M $\left.+\mathrm{Na}\right]^{+}$; HR-ESI-MS: $m / z 477.1747$ $[\mathrm{M}+\mathrm{Na}]^{+}$(calcd for $\left.\mathrm{C}_{22} \mathrm{H}_{30} \mathrm{O}_{10} \mathrm{Na}, 477.1737\right)$; $\mathrm{UV}\left(\mathrm{CH}_{3} \mathrm{OH}\right) \lambda_{\max }$ ( $\log \varepsilon$ ): 204 (3.9), 232 (3.9), IR (KBr) $\nu_{\text {max }}$ : 3366, 2880, 2357, 1700, 1414, $1070 \mathrm{~cm}^{-1} ;{ }^{1} \mathrm{H}$ and ${ }^{13} \mathrm{C}$ NMR data see Table 1.

Lonimacranalde $\mathbf{B}$ (2). White powder; $[\alpha]_{\mathrm{D}}^{28}-9.7$ (c 0.6 , $\mathrm{CH}_{3} \mathrm{OH}$ ); ESI-MS: $m / z 477$ [M + Na] ${ }^{+}$; HR-ESI-MS: $m / z 477.1738$ $[\mathrm{M}+\mathrm{Na}]^{+}$(calcd for $\left.\mathrm{C}_{22} \mathrm{H}_{30} \mathrm{O}_{10} \mathrm{Na}, 477.1737\right)$; $\mathrm{UV}\left(\mathrm{CH}_{3} \mathrm{OH}\right) \lambda_{\max }$ $(\log \varepsilon): 206$ (4.1), 230 (3.9); IR (KBr) $\nu_{\text {max }}: 3389,2891,2345,1678$, 1621, 1274, $1070 \mathrm{~cm}^{-1} ;{ }^{1} \mathrm{H}$ and ${ }^{13} \mathrm{C}$ NMR data see Table 1.

Lonimacranalde $\mathrm{C}$ (3). Light yellow powder; $[\alpha]_{\mathrm{D}}^{28}-150.4(c$ 0.3, $\mathrm{CH}_{3} \mathrm{OH}$ ); ESI-MS: $m / z 455[\mathrm{M}-\mathrm{H}]^{-}$; HR-ESI-MS: $\mathrm{m} / \mathrm{z}$ 479.1895 $[\mathrm{M}+\mathrm{Na}]^{+}$(calcd for $\mathrm{C}_{22} \mathrm{H}_{32} \mathrm{O}_{10} \mathrm{Na}, 479.1893$ ); UV $\left(\mathrm{CH}_{3} \mathrm{OH}\right) \lambda_{\max }(\log \varepsilon): 204$ (3.9), 234 (4.2); IR (KBr) $\nu_{\max }: 3400$, 2926, 2357, 1675, 1627, 1272, $1070 \mathrm{~cm}^{-1} ;{ }^{1} \mathrm{H}$ and ${ }^{13} \mathrm{C}$ NMR data see Table 1.

\section{X-ray crystallographic analysis}

Crystal data for compound (1). Data were collected using a Sapphire CCD with a graphite monochromated $\mathrm{Cu} \mathrm{K} \alpha$ radiation, $\lambda=1.54184 \AA$ at $150 \mathrm{~K}$. Crystal data: $\mathrm{C}_{22} \mathrm{H}_{30} \mathrm{O}_{10}, M=$ $\sim 454$, space group $P 2_{1}$; unit cell dimensions were determined as $a=13.1270(2) \AA, b=7.9802(1) \AA, c=13.2754(2) \AA, \alpha=90.00^{\circ}$, $\beta=116.561(2)^{\circ}, \gamma=90.00^{\circ}, V=1243.90(4), Z=2, D_{x}=$ $1.336 \mathrm{~g} \mathrm{~m}^{-3}, F(000)=536.0, \mu(\mathrm{Cu} \mathrm{K} \alpha)=0.888 \mathrm{~mm}^{-1} .23017$ unique reflections were collected until $\theta_{\max }=74.16^{\circ}$, in which 4804 reflections were observed $\left[F^{2}>4 \sigma\left(F^{2}\right)\right]$. The structure was solved by direct methods using the SHELXS-97 program, and refined by the program SHELXL-97 and full-matrix least-squares calculations. In the structure refinements, non-hydrogen atoms were placed on the geometrically ideal positions by the "ride on" method. Hydrogen atoms bonded to oxygen were located by the structure factors with isotropic temperature factors. The final refinement gave $R=0.0360(4804), R_{\mathrm{w}}=0.0899(4915), S=1.042$, and flack $=-0.01(8)$. Crystallographic data for structure 1 has been deposited at the Cambridge Crystallographic Data Centre (CCDC 1877498).

\section{Anti-inflammatory activity assays}

Cell culture and viability. RAW 264.7 murine macrophage cell line was obtained from Chinese Academy of Sciences. The cells were grown in DMEM (Gibco, USA) containing 10\% FBS (Gibco, USA), $100 \mathrm{U} \mathrm{mL}^{-1}$ penicillin, and $100 \mu \mathrm{g} \mathrm{m}^{-1}$ streptomycin. They were cultured at $37{ }^{\circ} \mathrm{C}$ in $5 \% \mathrm{CO}_{2}$. Cell viability was analyzed using MTT assay. Compounds was added to the cells and incubated for $1 \mathrm{~h}$ and then cells were treated with or without LPS for $18 \mathrm{~h}$ at $37{ }^{\circ} \mathrm{C}$ with $5 \% \mathrm{CO}_{2}$. MTT solution $(5 \mathrm{~g}$ $\mathrm{L}^{-1}$ ) was added to each well and incubated for $4 \mathrm{~h}$ at $37^{\circ} \mathrm{C}$. The formazan dyes in the cells were dissolved in $100 \mu \mathrm{L} 10 \%$ SDS$\mathrm{HCl}$ solution. The optical density was read at $570 \mathrm{~nm}$ (reference, $650 \mathrm{~nm}$ ) using a microplate UV/VIS spectrophotometer (Tecan, Mannedorf, Switzerland). The cell viability in the control group (cells were not treated by compounds and LPS) was set as $100 \%$.

Effect of compounds 1-3 on the PGE 2 , NO, TNF- $\alpha$ and IL-6 production. Cells were seeded in a 96-well plate at a density of $1 \times 10^{4}$ cells per well in DMEM and incubated for $24 \mathrm{~h}$. The cells were pretreated with the compounds for $30 \mathrm{~min}$ and treated with LPS $\left(1 \mu \mathrm{g} \mathrm{mL}{ }^{-1}\right)$ for $24 \mathrm{~h}$ in the presence or absence of different concentrations of the compounds. The supernatant of the cell culture $(100 \mu \mathrm{L})$ was harvested, and the concentration of NO was mixed with Griess reagent (100 $\mu \mathrm{L}$, Sigma) at room temperature for $10 \mathrm{~min}$. Absorbance was recorded at $550 \mathrm{~nm}$ with a microplate reader (Varioskan LUX, Thermo Fisher Scientific Inc., Waltham, MA, USA). The concentration of $\mathrm{PGE}_{2}$, TNF- $\alpha$ and IL- 6 in the culture medium was determined using commercial ELISA kits according to the instructions. The $\mathrm{IC}_{50}$ values were calculated from calibration curves of the absorbance inhibition by each compound at three concentrations against the increasing absorbance of macrophage cells stimulated only with LPS (without the compounds). Data were obtained from three independent experiments $(n=3)$.

Data analysis. The data obtained are presented as the means \pm SD of three independent experiments. A one-way analysis of variance (ANOVA) test was used for statistical analysis, followed by a Dunnett's post hoc test for multiple comparisons. GraphPad 
Prism 5.02 (GraphPad Software Inc., San Diego, CA, USA) was used to perform the analyses.

\section{Conflicts of interest}

There are no conflicts to declare.

\section{Acknowledgements}

This work was supported by grants from the National Natural Science Foundation of China (program no. 81630097, 81602984 and 81803347). The authors are grateful to State Key Laboratory of New-Tech for Chinese Medicine Pharmaceutical Process, Jiangsu Kanion Pharmaceutical Co. Ltd. for their assistance of activity test.

\section{Notes and references}

1 M. Wink, Phytochemistry, 2003, 64, 3-19.

2 W. Gu, X. J. Hao, H. X. Liu, Y. H. Wang and C. L. Long, Phytochem. Lett., 2013, 6, 681-685.

3 K. Hase, Q. Xiong and S. Kadota, Stud. Nat. Prod. Chem., 2001, 25, 459-482.

4 M. X. Li, X. F. Shang, R. X. Zhang, Z. P. Jia, P. C. Fan, Q. Ying and L. L. Wei, Fitoterapia, 2010, 81, 167-172.

5 Z. D. Nan, M. B. Zhao, K. W. Zeng, S. H. Tian, W. N. Wang, Y. Jiang and P. F. Tu, Chin. J. Nat. Med., 2016, 14, 61-65.

6 C. Wang, P. Xin, Y. Wang, X. Zhou, D. Wei, C. Deng and S. Sun, Fitoterapia, 2018, 124, 152-159.

7 C. Wang, X. Zhou, Y. Wang, D. Wei, C. Deng, X. Xu, P. Xin and S. Sun, Molecules, 2017, 22, 2101.

8 N. Chaipukdee, K. Kanokmedhakul, S. Kanokmedhakul, R. Lekphrom and S. G. Pyne, Fitoterapia, 2016, 113, 97-101.

9 A. E. Ayeb-Zakhama, A. Beyaoui, S. B. Salem, L. Sakka-Rouis, J. Bouajila, H. B. Jannet and F. Harzallah-Skhiri, Ind. Crops Prod., 2015, 76, 653-659.
10 R. D. Sonawane, V. B. Deore, S. D. Patil, C. R. Patil, S. J. Surana and R. K. Goyal, Physiol. Behav., 2015, 144, 66-72.

11 C. M. Camero, M. P. Germanò, A. Rapisarda, V. D'Angelo, S. Amira, F. Benchikh, A. Braca and M. D. Leo, Rev. Bras. Farmacogn., 2018, 28, 374-377.

12 E. L. Ghisalberti, Phytomedicine, 1998, 5, 147-163.

13 J. A. Pérez, J. M. Hernández, J. M. Trujillo and H. López, Stud. Nat. Prod. Chem., 2005, 32, 303-363.

14 Y. D. Mei, N. Zhang, W. Y. Zhang, J. S. Tang, H. Zhou, Y. Yu and X. S. Yao, Chin. J. Nat. Med., 2019, 17(4), 27-32.

15 Y. D. Mei, D. B. Pan, Y. N. Jiang, W. Y. Zhang, X. J. Yao, Y. Dai, Y. Yu and X. S. Yao, Fitoterapia, 2019, 134, 297-304.

16 N. Ikeda, M. Ishihara, T. Tsuneya, M. Kawakita, M. Yoshihara, Y. Suzuki, R. Komaki and M. Inui, Flavour Fragrance J., 1994, 9, 325-331.

17 Y. Yu, W. X. Song, C. G. Zhu, S. Lin, F. Zhao, X. L. Wu, Z. G. Yue, B. Liu, S. J. Wang, S. P. Yuan, Q. Hou and J. G. Shi, J. Nat. Prod., 2011, 74, 2151-2160.

18 R. E. Krull and F. R Stermitz, Phytochemistry, 1998, 49, 24132415.

19 K. Miettinen, L. Dong, N. Navrot, T. Schneider, V. Burlat, J. Pollier, L. Woittiez, S. V. D. Krol, R. Lugan, T. Ilc, R. Verpoorte, K. Oksman-Caldentey, E. Martinoia, H. Bouwmeester, A. Goossens, J. Memelink and D. WerckReichhar, Nat. Commun., 2014, 5, 4175.

20 W. X. Song, S. Li, S. Wang, Y. Wu, J. C. Zi, M. L. Gan, Y. L. Zhang, M. T. Liu, S. Lin, Y. C. Yang and J. G. Shi, J. Nat. Prod., 2008, 71, 922-925.

21 Y. Yu, C. G. Zhu, S. J. Wang, W. X. Song, Y. C. Yang and J. G. Shi, J. Nat. Prod., 2013, 76, 2226-2233.

22 R. Iafe and K. N. Houk, Org. Lett., 2006, 8, 3469-3472.

23 B. Moreau, M. Ginisty and D. A. Alberico, J. Org. Chem., 2007, 72, 1235-1240. 